\title{
Design of a Stable System by Lean Manufacturing
}

\author{
Daniela Gîfu ${ }^{1}$, Mirela Teodorescu ${ }^{2, *}$, Dan lonescu ${ }^{3}$ \\ 1"Alexandru Ioan Cuza" University of Iaşi, Bulevardul Carol I, No. 11, 700506, Iaşi, Romania \\ 2University of Craiova, 13 A. I. Cuza Street, Craiova, 200585, Romania \\ 3"Nicolae Titulescu” High School, Doljului Street, Craiova, Romania \\ *E-mail address: mirteodorescu@yahoo.com
}

\begin{abstract}
Markets are organized so that buyers and sellers have a choice of participating in production-tostock or production-to-order auctions. A production-to-stock (PTS) institution requires the seller to hold inventory before trading. Data from computerized double auctions are analyzed. Inventory cost diminishes trading activity. When the choice of institution is endogenous, sales from stock are about 15 percent of the total. When there is only a PTS market, econometric estimates show sellers as a group seek higher prices and seller surplus is relatively high. A production-to-order choice increases buyer surplus and market efficiency: doing more with less by employing 'lean thinking.' Lean manufacturing involves never ending efforts to eliminate or reduce 'waste' in design, manufacturing, distribution, and customer service processes. Developed by the Toyota executive Taiichi Ohno during post-Second World War reconstruction period in Japan, and popularized by James P. Womack and Daniel T. Jones in their 1996 book 'Lean Thinking.' Also is called lean production. The core idea is to maximize customer value while minimizing waste. Simply, lean means creating more value for customers with fewer resources. A lean organization understands customer value and focuses its key processes to continuously increase it. The ultimate goal is to provide perfect value to the customer through a perfect value creation process that has zero waste. To accomplish this, lean thinking changes the focus of management from optimizing separate technologies, assets, and vertical departments to optimizing the flow of products and services through entire value streams that flow horizontally across technologies, assets, and departments to customers. Lean thinking involves: specify what creates value from the customers perspective, identify all steps across the whole value stream, making those actions that create value flow, making what is pulled by the customer just-in-time, strive for perfection by continually removing successive layers of waste.
\end{abstract}

Keywords: lean manufacturing; improvement; process control; efficiency; six sigma

\section{INTRODUCTION}

A fundamental principle of lean manufacturing is demand-based flow manufacturing. In this type of production setting, inventory is only pulled through each production center when it is needed to meet a customer's order. The benefits of this goal include (Hopp \& Spearman, 2008): decreased cycle time, increase JPH (jobs per hour); less inventory, decrease waste, decrease costs; increased productivity, increase OEE of equipment; increased capital equipment utilization. 
There are several tools for lean implementation founded on the concept of continuous product and process improvement and the elimination of non-value added activities(Womack, Jones \& Roos, 1990). The Value adding activities "are simply only those things the customer is willing to pay for, everything else is waste, and should be eliminated, simplified, reduced, or integrated" (Rizzardo, 2003). Improving the flow of material through new ideal system layouts at the customer's required rate would reduce waste in material movement and inventory(Hopp \& Spearman, 2008; Borowski, 2013).

\section{METHODS OF LEAN MANUFACTURING IMPLEMENTATION}

2.1. Continuously improvement - Kaizen. A continuous improvement mindset is essential to reach the company's goals. The term "continuous improvement" means incremental improvement of products, processes, or services over time, with the goal of reducing waste to improve workplace functionality, customer service, or product performance (Suzaki, 1987).

Stephen Shortell (Professor of Health Services Management and Organizational Behavior - Berkeley University, California) states: "For improvement to flourish it must be carefully cultivated in a rich soil bed (a receptive organization), given constant attention (sustained leadership), assured the right amounts of light (training and support) and water (measurement and data) and protected from damaging." PDCA is an iterative four-step management method used in business for the control and continuous improvement of processes and products (Rother, 2010; Siminică \& Traistaru, 2013; Traistaru \& Avram, 2014). Plan Establish the objectives and processes necessary to deliver results in accordance with the expected output (the target or goals) (Vlăduţescu \& Dima, 2012; Vlăduţescu, 2013). By establishing output expectations, the completeness and accuracy y of the spec is also a part of the targeted improvement. When possible start on a small scale to test possible effects. DoImplement the plan, execute the process, make the product. Collect data for charting and analysis in the following "CHECK" and "ACT" steps.

Check -Study the actual results (measured and collected in "DO" above) and compare against the expected results (targets or goals from the "PLAN") to ascertain any differences. Look for deviation in implementation from the plan and also look for the appropriateness and completeness of the plan to enable the execution, i.e., "Do". Charting data can make this much easier to see trends over several PDCA cycles and in order to convert the collected data into information. Information is what you need for the next step "ACT". Act- Request corrective actions on significant differences between actual and planned results. Analyze the differences to determine their root causes. Determine where to apply changes that will include improvement of the process or product. When a pass through these four steps does not result in the need to improve, the scope to which PDCA is applied may be refined to plan and improve with more detail in the next iteration of the cycle, or attention needs to be placed in a different stage of the process (Womack, James, Jones, 2003; Stoica, 2007).

2.2. Overall Equipment Effectiveness (OEE) is a set of performance metrics that fit well in a lean environment and represents a measurement. Overall equipment effectiveness (OEE) and total effective equipment performance (TEEP) are two closely related measurements that report the overall utilization of facilities, time and material for manufacturing operations. These indicators show the gap between actual and ideal performance. Overall equipment effectiveness quantifies how well a manufacturing unit performs relative to its designed capacity, during the periods when it is scheduled to run. 
Total effective equipment performance (TEEP) measures OEE against calendar hours, i.e.: 24 hours per day, 365 days per year (Krafcik, 1988).

The OEE is measured as : (Availability)*(Performance)*(Quality). Where:

- Availability: The portion of the OEE Metric that represents the percentage of scheduled time that the operation is available to operate. Often is referred as Uptime.

- Performance: The portion of the OEE Metric that represents the speed at which the Work Center runs as a percentage of its designed speed.

- Quality: The portion of the OEE Metric that represents the Good Units produced as a percentage of the Total Units Started.

2.3. Six Sigma is a set of techniques and tools for process improvement. It was developed by Motorola in 1986, coinciding with the Japanese asset price bubble which is reflected in its terminology. Six Sigma became famous when Jack Welch made it central to his successful business strategy at General Electric in 1995 (Womack, Jones \& Roos, 1990; Holweg, 2007; Bailey, 2008; Krafcik, 1988). Six Sigma seeks to improve the quality of process outputs by identifying and removing the causes of defects (errors) and minimizing variability in manufacturing and business processes. It uses a set of quality management methods, including statistical methods, and creates a special infrastructure of people within the organization ("Champions", "Black Belts", "Green Belts", "Yellow Belts", etc.) who are experts in the methods. Each Six Sigma project carried out within an organization follows a defined sequence of steps and has quantified value targets, for example: reduce process cycle time, improve environment quality, reduce costs, increase customer satisfaction, and increase profits (Vlăduţescu \& Ciupercă, 2013; Dascălu, 2013; Smarandache \& Vlăduţescu, 2014).

The term Six Sigma originated from terminology associated with manufacturing, specifically the term "six sigma" comes from statistics and is used in statistical quality control, which evaluates process capability. Originally, it referred to the ability of manufacturing processes to produce a very high proportion of output within specification. Processes that operate with "six sigma quality" over the short term are assumed to produce long-term defect levels below 3.4 defects per million opportunities (Tennant, 2001; Motorola University Six Sigma Dictionary). Six Sigma means continuous efforts to achieve stable and predictable process results (i.e., reduce process variation) are of vital importance to business success, manufacturing and business processes have characteristics that can be measured, analyzed, controlled and improved, achieving sustained quality improvement requires commitment from the entire organization, particularly from top-level management (Harry \& Schroeder, 2000). Features of Six Sigma apart of previous quality improvement goals stipulate: focusing on projects to achieve measurable and quantifiable financial returns, to support by a strong management leadership the projects, to offer a clear commitment to making decisions on the basis of verifiable data and statistical methods, rather than assumptions and guesswork.

The Six Sigma project methodology is based on five phases (DMAIC):

1. Define the system, the VOC (voice of the customer) and their requirements, CTQ (critical to quality) and the project goals, specifically.

2. Measure key aspects of the current process, define process measures, identify types, sources and causes of variation in processes, determine data requirements for Six Sigma project, develop a Data Collection Plan, perform Measurement System Analysis (MSA), determines the baseline capability as a Sigma value.

3. Analyze the data to investigate and verify cause-and-effect relationships. Determine what the relationships are, and attempt to ensure that all factors have been considered. Seek out 
root cause of the defect under investigation. The Analyze Phase allows the Project Team to target further improvement opportunities by taking a closer look at the process and the data collected in the Measure Phase.

4. Improve or optimize the current process based upon data analysis using techniques such as design of experiments, poka yoke (process that helps an equipment operator avoid mistakes) or error proofing, and standard work to create a new, future state process. Conduct a process improvement pilot, analyze Process capability to validate improvement gains.

5. Control the future state process to ensure that any deviations from target are corrected before they result in defects. Control is a mean of sustaining improvement by either eliminating the opportunity for detect (preferred) or monitoring the process and using a formal feedback system. Implement control systems such as statistical process_control, production boards, visual workplaces, and continuously monitor the process. Need to establish an effective strategy to ensure improvements are sustained.

2.4. Policy Deployment - translates the strategic intent of the organization into the required day to day behavior. It is a management system to ensure all of the company's resources are aligned to support the few strategic goals of the organization. Policy Deployment comes from Hoshin Kanri. Hoshin means pointing in a direction. Kanri means management or control. We have to introduce a process to ensure that corrective actions that have been implemented are verified and stability is achieved. If stability is not achieved, then the process is reviewed and all applicable modifications/changes will be made (Hutchins, 2008; Bosun \& Grabara, 2014; Bosun \& Modrak, 2014; Lis \& Bajdor, 2013). This process is composed of four actions: Plan, Do, Check, Act. Plan means that the organization determines its goals and the methods to achieve them, Do means that the organization implements the methods, Check means the results and identify obstacles, Act if goal was achieved then standardize the process or start with the planning stage and modify the process. Policy Deployment systematizes strategic planning through seven-step process, in which are performed the following management tasks: Identify the key business issues facing the organization, establish measurable business objectives that address these issues, define the overall vision and goals, develop supporting strategies for pursuing the goals. In the Lean organization, this strategy includes the use of Lean methods and techniques, determine the tactics and objectives that facilitate each strategy, implement performance measures for every business process, measure business fundamentals (Dale, 1990).

2.5. The 5 Whys is an iterative question-asking technique used to explore the cause-andeffect relationships supporting a particular problem (Womack, Jones \& Roos, 1990). The primary goal of the method is to determine the root cause of a defect or issue. The "5" in the name derived from an empirical observation on the number of iterations typically required to resolve the problem. The reason for a problem can often lead into another question; you may need to ask the question fewer or more than five times before you get to the origin of a problem.

The real key is to avoid assumptions and logic traps and encourage the team to keep drilling d How to complete the five why-s :

- Write down the specific problem. Writing it down helps you formalize the problem and describe it accurately. It also helps a team focus on the same problem;

- Use brainstorming to ask why the problem occurs then, write the answer down below;

- If this answer doesn't identify the source of the problem, ask 'why?' again and write that answer down; 
- Loop back to step three until the team agrees that they have identified the problem's root cause. Again, this may take fewer or more than five 'whys?'

The benefits of the 5 Whys method: helps you to identify the root causes of a problem, helps you to determine the relationship between different root causes of a problem, it is one of the simplest analysis tools as it's easy to complete without statistical analysis, it is easy to learn and apply (Ohno, 1988 ). A key phrase to keep in mind in any 5 Why exercise is "people do not fail, processes do". Criticism-the 5 Whys is a powerful tool for engineers or technically savvy individuals to help get to the true causes of problems, it has also week poets as tendency for investigators to stop at symptoms rather than going on to lower-level root causes, Inability to go beyond the investigator's current knowledge - cannot find causes that they do not already know, lack of support to help the investigator ask the right "why" questions, tendency to isolate a single root cause, whereas each question could elicit many different root causes (Ohno, 1988; Vlăduţescu, 2007; Vlăduţescu, 2008; Vlăduţescu, 2010).

2.6. Ishikawa diagrams (also called fishbone diagrams, cause-and-effect diagrams) are causal diagrams created by Kaoru Ishikawa (1968) that show the causes of a specific event (Womack, Jones \& Roos,1990; Holweg, 2007; Hristea \& Colhon, 2012; Colhon, 2013). Common uses of the Ishikawa diagram are product design and quality defect prevention, to identify potential factors causing an overall effect. Each cause or reason for imperfection is a source of variation. Causes are usually grouped into major categories to identify these sources of variation such as: people, methods, machines, materials, measurements, environment (Bajdor \& Grabara, 2014; Kot, Grabara \& Kolcun, 2014).

Related to these categories can be extended to detailed items like anyone involved with the process, how the process is performed and the specific requirements for doing it, policies, procedures, rules, regulations and laws, any equipment, computers, tools, etc. required to accomplish the job, raw materials, parts, pens, paper, etc. used to produce the final product, data generated from the process that are used to evaluate its quality, the conditions, such as location, time, temperature, and culture in which the process operates. Causes can be derived from brainstorming sessions. These groups can then be labeled as categories of the fishbone. They will typically be one of the traditional categories mentioned above but may be something unique to the application in a specific case.

\section{CONCLUSIONS}

Lean is a culture of continuous improvement practiced at every level of the organization and by every team. Lean is the application of the scientific method of experimentation and study of work processes and systems to find improvements. Lean is respect for people. It is respect for the voice of the customer and it is respect for those who do the work, who are "onthe-spot" and are, therefore, the "world's greatest experts" in their work. Lean is a work environment that assures the quality and safety of all work for both clients and staff (Teodorescu \& Ionescu, 2014). Lean is a culture of teamwork, shared responsibility and ownership that cuts through organization walls or silos (Teodorescu, 2014). Lean is flow. Lean is an interruption free process that flows from beginning to end without interruption (Miller, 2009). The truth is that the communication process must be a clear and concise one. It's a twoway street and we need to make sure the recipient understands the intention of the communication as well as the content. It may appear to be an extra step in the process; however, confirming the correct translation of a communication string is critical to the success of value- 
added communication. Lean process is a successful process in conditions of a sustainable, durable and stable system, implemented by means of above mentioned methods.

\section{ACKNOWLEDGMENT}

This work was partially supported by the grant number 33C/2014, awarded in the internal grant competition of the University of Craiova.

\section{References}

[1] J. P. Womack, D. T. Jones, D. Roos (1990). The Machine That Changed the World. MIT Press.

[2] M. Holweg, Journal of Operations Management 25(2) (2007) 420-437.

[3] D. Bailey (2008). Automotive News calls Toyota world No 1 car maker. Reuters. Retrieved 19 April 2008: Reuters.com.

[4] Andrzej Borowski, International Letters of Social and Humanistic Sciences 14 (2014) 7-17.

[5] Ş. Vlăduţescu, E. M. Ciupercă (2013). Next Flood Level of Communication: Social Networks. Aachen: Shaker Verlag.

[6] Lawrence M. Miller (2009). Lean Team Management: How to Create Lean Management \& Lean Organization. L. M. Miller Publishing.

[7] Andrzej Borowski, International Letters of Social and Humanistic Sciences 11 (2014) $1-168$.

[8] Ştefan Vlăduţescu, European Scientific Journal 9(32) (2013).

[9] Mike Rother (2010). 6 Toyota Kata. New York: McGraw-Hill.

[10] W. Hopp, M. Spearman (2008). Factory Physics: Foundations of Manufacturing Management.

[11] Geoff Tennant (2001). SIX SIGMA: SPC and TQM in Manufacturing and Services. Gower Publishing Ltd.

[12] Andrzej Borowski, International Letters of Social and Humanistic Sciences 3 (2013) 69-74.

[13] Ioan Constantin Dima, Ştefan Vlăduţescu (2012).The Environment of Organizational Entities and its Influence on Decisional Communication. International.

[14] Marian Siminică, Aurelia Traistaru, International Journal of Education and Research 1(12) 2013.

[15] Ştefan Vlăduţescu (2014). Convictive Communication and Persuasive Communication. International.

[16] Paula Bajdor, Iwona Grabara (2014). The Role of Information System Flows in Fulfilling Customers' Individual Orders. Journal. 
[17] Aurelia Traistaru, Marioara Avram, International Letters of Social and Humanistic Sciences 13 (2014) 79-88.

[18] Sebastian Kot, Janusz Grabara, Michal Kolcun (2014). Use of elements of semiotic language in tourism marketing. International.

[19] Petre Bosun, Vladimir Modrak, International Letters of Social and Humanistic Sciences 14 (2014) 66-72.

[20] Ştefan Vlăduţescu (2013). What Kind of Communication Is Philosophy. Jokull.

[21] J. F. Krafcik, Sloan Management Review (1988).

[22] Andrzej Borowski, International Letters of Social and Humanistic Sciences 4 (2013) 70-74.

[23] B. M. Dascălu (2014). Echivocul imagologic în Caietele lui Emil Cioran. Studii de Ştiinţă şi Cultură.

[24] J. P. Womack, D. T. Jones (2003). Lean Thinking. Free Press.

[25] F. Hristea, M. Colhon (2012). Feeding syntactic versus semantic knowledge to a knowledge-lean unsupervised word sense disambiguation algorithm with an underlying Naïve Bayes model. Fundamenta Informaticae.

[26] Andrzej Borowski, International Letters of Social and Humanistic Sciences 2 (2014) 110-121.

[27] Ştefan Vlăduţescu (2014). Communication on the difficult route of lie. International.

[28] Petre Bosun, Janusz Grabara, International Letters of Social and Humanistic Sciences 14 (2014) 59-65.

[29] Ioan Constantin Dima, Ştefan Vlăduţescu (2012). Persuasion elements used in logistical negotiation: Persuasive logistical negotiation. Saarbrucken: LAP Lambert Academic Publishing.

[30] Janusz Grabara, Michal Kolcun, Sebastian Kot (2014). The Role of Information Systems in Transport Logistics. International.

[31] F. Smarandache, Ş. Vlăduţescu (2014). Neutrosophic Emergences and Incidences in Communication and Information. Saarbrucken: LAP Lambert Academic Publishing.

[32] Tomasz Lis, Paula Bajdor (2013). Sales Logistics as a Model Used by Companies Fulfilling Individual Customer's Needs. In: Challenges in Contemporary Management. Monograph. Scientific Editors Anna Lemańska-Majdzik, Piotr Tomski, Sekcja Wydaw. WZ PCzęst, Czestochowa.

[33] Andrzej Borowski, International Letters of Social and Humanistic Sciences 6 (2013) 86-90.

[34] Ştefan Vlăduţescu (2008). Comunicarea managerială negativă în activitatea publicistică. Craiova: Editura Arves.

[35] Colhon, M. (2013). Automatic Lexical Alignment between Syntactically Weak Related Languages. Application for English and Romanian. In Computational Collective Intelligence. Technologies and Applications (pp. 266-275). Springer Berlin Heidelberg. 
[36] B. M. Dascălu (2006). Germanitatea şi literele române. Bucureşti: Editura Fundaţia Culturală Ideea Europeană.

[37] I. Iancu, N. Constantinescu, M. Colhon, International Journal of Computers Communications \& Control 4(5) (2010) 525-531.

[38] Andrzej Borowski, International Letters of Social and Humanistic Sciences 4 (2013) 70-74.

[39] Ştefan Vlăduţescu (2014). From Personal and Social Relationships to Social Networks. International.

[40] Colhon M. (2013). Automatic Lexical Alignment between Syntactically Weak Related Languages. Application for English and Romanian. In Computational Collective Intelligence. Technologies and Applications (pp. 266-275). Springer Berlin Heidelberg.

[41] Petre Bosun, Mirela Teodorescu, Bianca Teodorescu (2014). Corporate Social Responsibility - Collaborating for the Future. International.

[42] T. Ohno (1988). Toyota Production System. Productivity Press.

[43] Jacek Tittenbrun, International Letters of Social and Humanistic Sciences 9 (2014) $26-48$.

[44] Ștefan Vlăduțescu (2013). Principle of the Irrepressible Emergence of the Message. Jokull.

[45] Jason L. Powell, International Letters of Social and Humanistic Sciences 7 (2014) 22-30.

[46] Motorola University Six Sigma Dictionary. Archived from the original on 2006-01-28. Retrieved 2014-04-28.

[47] M. Teodorescu, International Letters of Social and Humanistic Sciences 15(1) (2014) 53-62.

[48] Mikel Harry, Richard Schroeder (2000). Six Sigma. Random House Inc.

[49] Ştefan Vlăduţescu (2007). Eseuri de poetică şi retorică. Craiova : Editura Sitech.

[50] M. Teodorescu, D. Ionescu, International Letters of Social and Humanistic Sciences 14 (2014) 50-58.

[51] David Hutchins (2008). Hoshin Kanri: The Strategic Approach to Continuous Improvement. Gower Publishing.

[52] Andrzej Borowski, International Letters of Social and Humanistic Sciences 7 (2013) 113-118.

[53] B. G. Dale, The TQM Magazine (1990) 321-324.

[54] B. Teodorescu, International Letters of Social and Humanistic Sciences 15 (2014) 157-163.

[55] Ştefan Vlăduţescu (2010). Formule existenţiale şi adresări literare. Craiova: Editura Sitech.

[56] Janusz Grabara, Vladimir Modrak, Ioan Constantin Dima, International Letters of Social and Humanistic Sciences 15 (2014) 148-156. 
[57] D. S. Stoica, Revista Transilvană de Ştiinţe ale Comunicării 5 (2007) 60-64.

[58] Andrzej Borowski, International Letters of Social and Humanistic Sciences 6 (2013) $68-74$.

[59] Jason L. Powell, International Letters of Social and Humanistic Sciences 16(1) (2014) 19-30.

[60] Kabiru Ibrahim Yankuzo, International Letters of Social and Humanistic Sciences 4 (2014) 1-8. 